\title{
Is Distance Education the Answer to the Nursing Shortage?
}

\author{
Susan Mee \\ Department of Nursing, The College of Staten Island, City University of New York, New York, USA \\ Email: Susan.mee@csi.cuny.edu
}

Received 18 January 2014; revised 18 February 2014; accepted 28 February 2014

Copyright @ 2014 by author and Scientific Research Publishing Inc.

This work is licensed under the Creative Commons Attribution International License (CC BY). http://creativecommons.org/licenses/by/4.0/

(c) (i)

\begin{abstract}
This study examined the effectiveness of distance education compared with campus based learning among nursing students. Distance education in nursing curricula is increasing. Academic nurse leaders must demonstrate the effectiveness of distance learning. This study is unique in that two cohorts, distance learners and campus learners, were taught synchronously by the same faculty member. Quantitative measures of student learning outcomes were compared using SPSS. There were no significant differences in learning outcomes between distance learners and campus learners. This study provides empiric support for distance education as a means to address the nursing shortage.
\end{abstract}

\section{Keywords}

Distance Education; Nursing; Nursing Shortage; IOM Report; Student Learning Outcomes; Campus Learning; Academic Nurse Leaders

\section{Introduction}

Distance education is here to stay. The priority for academic nurse leaders in search of constructivist, significant learning, is to adapt our pedagogy to meeting the needs of diverse learners in the 21st century virtual classroom [1]-[5]. Increased demand for nursing education has led to expansion of distance learning opportunities without adequate evidence in the nursing literature of the impact of distance education on student learning outcomes [6]. If expansion of academic nursing programs include distance learning opportunities, it is imperative that academic nurse leaders demonstrate the effectiveness of the distance learning environment [7]. This descriptive study examined the effectiveness of distance education compared with traditional campus based education by measuring quantitative student learning outcomes. This study is unique in that the cohorts were taught synchronously by the same faculty member. The purpose of the study is germane to the discipline of nursing; specifi- 
cally, the purpose is to determine if there was a significant difference in student learning outcomes between distance learners and campus based learners enrolled in the first course of an RN to BS completion program.

\section{Background}

There is a rising demand for Registered Nurses in the United States [8] [9]. The US Bureau of Labor Statistics [BLS] estimated that in the next decade, the number of new jobs for nurses will increase by 1.2 million [10]. This predicted shortage is attributed to several factors including the impact of the Affordable Care Act, the aging of the nursing workforce and the increase in life expectancy for the population of baby-boomers [8]. Compounding the demand for the education of new nurses, the Institute of Medicine [IOM] report of the Future of Nursing (2010), recommends that the current nursing workforce must increase baccalaureate education from its current level of $50 \%$ to $80 \%$. Additionally, the IOM has called for doubling the number doctorally prepared nurses in the workforce [11].

The future of nursing education must address a myriad of challenges: the nursing shortage, the recommendations of the IOM and the National League for Nursing, and global trends in nursing and health care including the increasing complexity of patient needs in both the hospital and community [12]-[14]. The American Association of Colleges of Nursing [AACN] has described programs of nursing as "struggling to expand capacity to meet the rising demand for care given the national move toward health care reform” [8]. One way for nursing faculty to expand their existing programs is to offer both programs of study and course sections in a distance education format. This enables students who have geographical barriers to enroll. It also permits colleges to broaden their search for faculty that may be "distance teachers". The current shortage of nursing faculty is a very real consideration for programs that wish to expand but are limited by their lack of qualified faculty [11] [15]. Academic programs must answer to several accreditors. In addition to following the guidelines of the IOM, nurse educators are required to follow the guidelines set forth by the Middle States Commission on Higher Education [MSCHE]. The MSCHE supports and expands distance learning offerings [16]. This paper provides evidence to support the use and expansion of distance education programs specific to nursing education.

\section{Method}

\subsection{Design}

The design of this study is descriptive. This study provides a comparison of student learning outcomes among RN to BS nursing students enrolled in the first course of a baccalaureate program. This study examined student learning outcomes in a convenience sample of baccalaureate nursing students enrolled in a seminar in professional development. This seminar is the first course in a BS completion program designed for RN's. Course prerequisites included an AAS or equivalent in nursing and either RN licensure or eligibility for state licensure. Course outcome data is routinely collected each semester to evaluate course effectiveness. Course outcome data includes individual class participation and discussion grades, midterm exam grades and final exam grades. No attempt to link students' identifying information was made. With College IRB approval, aggregate data was compiled from course outcome data.

\subsection{Hypothesis}

The study tested the null hypothesis; "There is no difference in student learning outcomes among students registered for campus based learning and distance learning environments.”

\subsection{Participants}

All participants were either AAS or AS graduate nurses, RN's, or completing their final semester of the college's AAS program. Congruent with the general college population of all college students, participants self selected to be either distance learners $(n=15)$ or campus based learners $(n=25)$ when registering for the course. Distance based learners participated in class discussion via a BlackBoard ${ }^{\circledR}$ platform. Campus based learners engaged in a seated classroom seminar each week, moderated by the instructor. The instructor was also the course coordinator with experience in teaching this course in both formats. This was a unique sample given that the seminars were taught synchronously by the same faculty member. All students had equal access to the professor 
during both traditional office hours and email conferences. Course examinations were administered concurrently for all groups in a proctored environment on campus. Students were apprised of examination dates on the first day of class. This did not present a hardship for the distance learners since they were enrolled in the college for other campus based courses in a seated environment.

\subsection{Measures}

Quantitative measures of student learning were assessed. Measures included the Midterm exam score, Final exam score and overall numeric course grade. The Midterm exam was a thirty question multiple choice objective exam; the final exam was a fifty question multiple choice objective exam. The final course grade was a composite of student participation in discussion (25\%), the Final exam (30\%) and the Midterm exam (30\%). The student participation in discussion grade was an objective measure of student participation using a reliable and valid instrument for each student every week [17]. This instrument for class participation has been widely used throughout the curriculum and adapted for use in both distance learning and campus based environments. The instrument is part of the course syllabus and is available to students from the first day of class. The exams were used in previous cohorts with similar grade distributions. In addition there was a significant correlation between scores on the midterm exam and scores on the cumulative final exam $(r=0.407, p=0.009)$.

\subsection{Data Analysis}

Data were analyzed using SPSS 20 [18]. Descriptive statistics were analyzed. A one tailed independent t test was used to compare the means of the groups on three criteria: midterm exam, final exam, and final course grade. Correlations among the outcome measures were analyzed.

\section{Findings}

There were no significant differences in learning outcomes between distance learners and campus based learners. For scores on the midterm examination, there were no significant differences between the distance learners $(\mathrm{m}=$ $73.53, s d=7.54)$ and the campus learners $(m=68.8, s d=9.71)$. The difference between the two means was not significant $(t=-1.615, d f=38)$. For scores on the final examination, there were no significant differences between the distance learners $(m=74.13, s d=10.01)$ and the campus learners $(m=77.2, s d=7.33)$. The difference between the two means was not significant $(t=1.116, d f=38)$. With respect to the overall course grade, there were no significant differences between the distance learners $(m=82.2, s d=7.71)$ and the campus learners $(m=82.96, s d=5.87)$. The difference between the two means was not significant $(t=0.348, d f=37)$.

\section{Conclusion}

There is a need for academic programs of nursing to expand distance course and curricular offering in order to meet the rising demands for nurses in the workforce [4] [19] [20]. Additionally, demand for distance education is rising [2] [8] [15]. The findings of this study provide empiric evidence to support the use of distance learning as a means to address the nursing shortage. This study offered a unique opportunity to examine student learning outcomes while controlling for the confounding variables of differences in instructor teaching style and temporal factors. The unique opportunity to compare two very similar cohorts under very comparable circumstances, in particular examination administration, access to faculty support, homogeneity of the cohorts is a strength of the study. The limitations of the study are related to factors that impinge on most pedagogical research; that is, this was a small sample in a singular setting.

\section{Implications for Future Research}

A strength of the study is that it invites the next logical question, which is: "If student learning outcomes among distance learners and campus learners are equivalent, is it because the teaching methods are adapted to the learner or the learner to the teaching method?” This study offers an answer to the first question. Each cohort was taught synchronously by the same faculty member. The lecture material was presented concurrently of both cohorts. The method of delivery was Blackboard ${ }^{\circledR}$ for the distance learners and group discussion for the campus based learners. The underlying assumption that was not tested in this study is that students who self select for 
either format may have inherent qualities that influence their course delivery selection. The unanswered questions herald the path of future inquiry. The direction of future research is for nurse educators to answer the question, "What are the qualities of successful distance learners and, having identified those qualities, how can we best advise students seeking additional professional distance education?"

The participants in this study self selected to be distance learners, which is typical of all distance learners [21]. Although self-selection is an inherent quality of distance learners, it is a limitation of the study because this study does not address the qualities of distance learners that: 1) influence their decision to enroll in distance courses or 2) support or detract from their academic achievement. Some researchers suggest that distance learners are qualitatively different than campus based learners [22]. The untested question is, "are distance learners different than campus learners in terms of their learning style, technological proficiency, information literacy or overall academic success?” This is the direction for future research.

Qualitative experiences of distance education faculty reflect that there are inherent differences among students who self-select for these this learning modality [23]. Students request distance learning programs and courses. Faculty engaged in distance education report that distance education is not a good fit for every student. Moallem (2007) suggests that learning style is a determinant of student success [24]. Additionally, students express a strong preference which implies that there are differences that drive these preferences [21]. The direction of future research therefore, should examine the qualities of successful distance learners in an effort to assist students who either require or desire distance courses or curricula [25].

\section{References}

[1] Blood-Siegfried, J.E., Short, N.M., Rapp, C.G., Hill, E., Talbert, S., Skinner, J. and Goodwin, L. (2008) A Rubric for Improving the Quality of Online Courses. International Journal of Nursing Scholarship, 5, 1-13. http://dx.doi.org/10.2202/1548-923X.1648

[2] Magnussen, L. (2008) Applying the Principles of Significant Learning in the E-Learning Environment. Journal of Nursing Education, 47, 82-86. http://dx.doi.org/10.3928/01484834-20080201-03

[3] Reilly, J.R., Gallagher-Lepak, S. and Killion, C. (2011) "Me and My Computer”: Emotional Factors in Online Learning. Nursing Education Perspectives, 33, 100-105. http://dx.doi.org/10.5480/1536-5026-33.2.100

[4] Ryan, M., Carlton, R.H. and Nagia, S. (2004) Reflections on the Role of Faculty in Distance Learning and Changing Pedagogies. Nursing Education, 25, 75-80.

[5] Summers, J.J., Waigandt, A. and Whittaker, T. (2005) A Comparison of Student Achievement and Satisfaction in an Online versus a Traditional Face to Face Statistics Class. Innovative Higher Education, 29, 233-250.

[6] Kummerow, A., Miller, M. and Reed, R. (2013) Baccalaureate Courses for Nurses Online and on Campus: A Comparison of Learning Outcomes. The American Journal of Distance Education, 26, 50-65. http://dx.doi.org/10.1080/08923647.2011.645679

[7] Meyer, K.A. (2002) Quality in Distance Education, ERIC Digest.

[8] American Association of Colleges of Nursing (2007) Alliance for Nursing Accreditation Statement on Distance Education Policies. http://www.aacn.nche.edu/education-resources/distance-education-policies

[9] American Nurses Association (2013) Nursing World: Nursing Shortage. http://www.nursingworld.org/MainMenuCategories/

[10] Bureau of Labor Statistics, US Department of Labor (2012-2013) Occupational Outlook Handbook. http://www.bls.gov/ooh/Healthcare/Registered-nurses.htm\#tab-6

[11] Institute of Medicine (2011) The Future of Nursing: Leading Change, Advancing Health. National Academies Press, Washington DC.

[12] Benner, P., Sutphen, M., Leonard, V. and Day, L. (2010) Educating Nurses: A Call for Radical Transformation. Jossey-Bass, San Francisco.

[13] Halstead, J. (2011) Assuring the Future of Nursing Education. Nursing Education Perspectives, 33, 73. http://dx.doi.org/10.5480/1536-5026-33.2.73

[14] Turale, S. (2011) Preparing Nurses for the 21st Century: Reflecting on Nursing Shortages and Other Challenges in Practice and Education. Nursing and Health Sciences, 13, 229-231.

[15] National League for Nursing (2010) Nurse Faculty Shortage Fact Sheet. http://www.nln.org/governmentaffairs/pdf/NurseFacultyShortage.pdf

[16] Middle States Commission on Higher Education (2011) Distance Education Programs: Interregional Guidelines for the 
Evaluation of Distance Education (Online Learning). Philadelphia.

[17] Lunney, M. and Sammarco, A. (2009) Scoring Rubric for Grading Students Participation in Online Discussions. Computers, Informatics, Nursing, 27, 26-31.

[18] IBM Corp. Released 2011. IBM SPSS Statistics for Windows, Version 20.0. IBM Corp, Armonk.

[19] National League for Nursing (2010) Nurse Faculty Shortage Fact Sheet. http://www.nln.org/governmentaffairs/pdf/NurseFacultyShortage.pdf

[20] Sizemore, M.H., Robbins, L.K., Hoke, M.M. and Billings, D.M. (2007) Outcomes of ADN-BSN Partnerships to Increase Baccalaureate Prepared Nurses. International Journal of Nursing Education Scholarship, 4, 1-18. http://dx.doi.org/10.2202/1548-923X.1479

[21] Leasure, A.R., Davis, L. and Thievon, S.L. (2000) Comparison of Student Outcomes and Preferences in a Traditional vs. World Wide Web-Based Baccalaureate Nursing Research Course. Journal of Nursing Education, 39, 149-154.

[22] Carbonaro, M., Dawber, T. and Arav, I. (2006) A Comparison of Students’ Performance under Full-Time, Part-Time, and Online Conditions in an Undergraduate Nursing Microbiology Course. Journal of Distance Education, 21, 51-61.

[23] Simpson, O. (2012) Supporting Students in Online, Open and Distance Learning. Routledge, New York.

[24] Moallem, M. (2007) Accommodating Individual Differences in the Design of Online Learning Environments: A Comparative Study. Journal of Research on Technology in Education, 40, 217-245. http://dx.doi.org/10.1080/15391523.2007.10782506

[25] Coose, C. (2011) Distance Learning in Alaska: A Longitudinal Study Nursing Education. Perspectives, 33, 93-96. 